This is the authors' copy of the accepted manuscript. For referencing, please use the original: Kallio, K.P. \& Bartos, A.E. (forthcoming) Children's caring agencies. Quest editorial in Political Geography doi:10.1016/j.polgeo.2016.09.009

\title{
Children's caring agencies
}

In June 2015, the United Nations High Commissioner for Refugees (UNHCR, 2015) declared the worldwide displacement of people at its all-time high. They identified nearly 60 million people as displaced in 2014 and presumed the numbers are still increasing. The past year has proved this right. In seeking for asylum and better life opportunities, people from conflict societies and deprived areas are moving in and across all continents ever more emergently'. Of them a half are children (UNHCR, 2015).

As displaced people, asylum seekers and refugees, children hold different positions from adults. They are entitled to undeniable protection by international agreements, most importantly the United Nations Convention on the Rights of The Child (UNCRC, 1989), which states that "[children] seeking refugee status [...] receive appropriate protection and humanitarian assistance in the enjoyment of applicable rights set forth in the present Convention [...] In cases where no parents or other members of the family can be found, the child shall be accorded the same protection as any other child permanently or temporarily deprived of his or her family environment." (Article 22).

$M$ any of the young refugees travel with their family members, but the number of unaccompanied children is also considerably high. In 2014, children lodged 34.300 asylum applications, coming mostly from Afghanistan, Eritrea, Syria, and Somalia (UNHCR, 2015). Their wellbeing and opportunities are solely in the hands of national actors and non-governmental humanitarian organizations who are obliged by the above agreement that, with its 42 Articles, guarantees children's provision, protection and participation rightsii.

Article 22 is often interpreted as a 'protection directive', emphasizing children as targets of adult-led protective measures (e.g. NGO Committee on Migration, 2015). Yet the Convention as a whole suggests a broader reading, emphasizing children's rights to protection and provision vis-à-vis their rights to participation (UNCRC 2009). This accentuates young persons as subjects with agency and considers asylum seeking and refugee children as vulnerable yet competent human beings (cf. Kallio, 2008; Evans, 2011; Eide $\&$ Hjern, 2013). This important point allows a shift in the discursive understandings of child refugees as only victims needing care and protection from others who know what is best for them, particularly states and INGOs. By bringing attention to these children, we hope to emphasize that the fragile life situations that make them extremely vulnerable in no way detracts from their opportunities for political agency. Rather, these children develop political subjectivities that are both a result of their vulnerabilities and are also fundamentally a result of being human.

To unpack our argument, we acknowledge that policy directives, INGOs and academic scholarship have gradually adopted many dimensions of children's agency (see e.g. recent publications in this journal). Yet one significant aspect of their agency remains unacknowledged: children's relationship to care. Children are 
This is the authors' copy of the accepted manuscript. For referencing, please use the original: Kallio, K.P. \& Bartos, A.E. (forthcoming) Children's caring agencies. Quest editorial in Political Geography doi:10.1016/j.polgeo.2016.09.009

still typically discussed as receivers instead of practitioners of care. A narrow stream of research has problematized this passive presumption, acknowledging children's engagements in a variety of care work (e.g. Robson, 2004; Evans \& Skovdal, 2016), but beyond caring labor their caring agencies have received little attention. We think this is problematic because care "offers the greatest possibility for transforming social and political thinking" (Tronto 1993: 124). It hence needs to be understood as a political project: an action that is both rooted in and results in political relationships that go beyond the caring agent or recipient of care and can lead toward social change.

Whether taking place in close communities or reaching afar, and involving personal matters or shared concerns, caring is an attitude and practice indivisible from political subjectivities that develop throughout the lifecourse and provide for political agency. As we have argued elsewhere, regardless of age, gender or citizenship status, people engage in caring activities that work to create and manipulate the worlds around them (Bartos, 2012, 2013; Kallio, 2016). These may have various consequences, including ones not readily accepted by all people within their sphere of influence. While care can lead to friendships, for instance, it can also create divisions and discrimination between 'us' and 'them,' which are often deeply felt in the root of more formal politics, not least immigration policies. On a more subtle level, caring practices can have incredibly constructive outcomes, like binding together people with nothing else in common but the shared experience where caring took place. We, therefore, strongly argue that children's caring agencies need to be understood and acknowledged as political.

Caring is specifically apparent in the case of asylum seeking and refugee children as it is one form of agency they can perform in these challenging circumstances. Like Erin Baines $(2015$, p.320) argues, in oppressed situations "people do more than navigate to survive"; people exert a variety of strategies to live their lives within traumatic situations and children are often no different from adults in this regard. Throughout the refugee process, whether that be along the physical journey of resettlement or within the processes and institutions that provide both obstacles and opportunities for asylum, children practice care actively. They care for their siblings, parents, grandparents and other family members, but also for their fellow travelers and neighbors in camps, and for the other children with whom they share their everyday life in reception centers, camps, homes, nurseries, schools, and public space. These include very practical forms of caring, like sharing food and running errands, but also more subtle, long-term ways of maintaining and creating caring relations with other children, youth, adults, and the elderly.

The studies by Marshall $(2013,2016)$ and Habashi $(2008,2016)$ portray richly how Palestinian children convey and perform care for their close ones and about other people, in the midst of the prolonged conflict. Ybarra and Peña (2016) similarly discuss children's caring agencies in the forced transnational familial lives of M exican-American families. Further, Kuusisto-Arponen (2011) and Ensor (2013) show that 
This is the authors' copy of the accepted manuscript. For referencing, please use the original: Kallio, K.P. \& Bartos, A.E. (forthcoming) Children's caring agencies. Quest editorial in Political Geography doi:10.1016/j.polgeo.2016.09.009

for displaced children, caring may involve transnational social and spatial relations, binding together past, present, and future communities. While these examples demonstrate a concern for others, in refugee situations children often take responsibilities also for themselves. In all, the actively upheld and generated caring relations are not unidirectional or supplementary to the care practiced by adults. As children work to continue, maintain or repair their worlds (vis-à-vis Tronto 1996), it requires adults to take notice of the specific ways that they engage in caring practices and politics, and deconstruct presumptions that prevent caring agency from being realized (e.g. Bartos 2012).

Paying attention to children's caring agencies has led us to raise two questions. First, do children's caring practices, particularly those whose opportunities to exert agency are constrained or challenged, suggest that care is a fundamental form of human agency? Second, what are the implications of children's caring agencies to the fulfillment of their rights to protection and provision as guaranteed under the UNCRC? We conclude this editorial by presenting some preliminary ideas regarding these questions, which we hope will lead to further debate and research.

A feminist ethic of care offers insight into the first question. Among others, Lawson (2007) has argued that care is fundamental to all human life: at some point or another, everyone will require care. Consequently, caring has (been) moved partly to institutional spaces and actors who practice care as work. In these relations, the roles of those who care and those who are cared for are given and clearly distinguished. However, in the mundane practices of care, people carry less fixed roles; everyday caring roles may be fluctuating and negotiable, while other times they are static. The fact that children also engage in these activities as providers and not only recipients confirms that all people may develop and manage responsibilities through caring activities. Our attention to children who are particularly vulnerable through their refugee and asylum status suggests that despite incredible hardships, care is present. On an everyday basis, children negotiate moments of dis-ease, inequality, suffering and conflict, which sets the stage for caring practices to develop. The pervasiveness of caring actions in difficult and troubling situations inspires us to consider that the conditions for care are always present and very often materialize into opportunities to exert agency. In which case, we suggest, future theorizations of care should take into consideration its potential to be understood as inherent to all forms of human agency.

In regards to the second question, we join in with the branch of critical research on children's rights that argues for a richer discussion about responsibilities and interdependencies (e.g. Ruck \& Horn, 2008; Kjørholt, 2013; Evans \& Skovdal, 2016; Punch \& Vanderbeck, forthcoming). At this time in history, the UNCRC is a significant achievement for children and children's rights advocates. However, even if seldom manifested, all rights it proposes are deeply interconnected to the responsibilities necessary to practice these rights. By not incorporating children's responsibilities into the interpretations of the UNCRC, children 
This is the authors' copy of the accepted manuscript. For referencing, please use the original: Kallio, K.P. \& Bartos, A.E. (forthcoming) Children's caring agencies. Quest editorial in Political Geography doi:10.1016/j.polgeo.2016.09.009

maintain subordinate and patronized positions where their active presence with others is not adequately acknowledged or encouraged. Both freedom and responsibility need to be included in any discussions of children's rights. Otherwise, their agencies appear less valuable and important. This would be a grave mistake in the case of asylum seeking children, for instance, whose everyday caring agencies result in incredible service to their families and other people with whom they share their lives, as well as to wider communities where they take responsible roles.

The African Union is currently the only UNCRC member group who considers the issue of responsibility explicitly. The African Charter on the Rights and Welfare of the Child (ACRWC 1990) emphasizes that children need to be prepared for "responsible life in a free society, in the spirit of understanding tolerance, dialogue, mutual respect and friendship among all peoples ethnic, tribal and religious groups" (Article 11D). It also details children's responsibilities "towards his family and society, the State and other legally recognized communities and the international community", including dimensions of respect, solidarity, and values (Article 31). The Charter hence acknowledges children as able, influential and important members of the communities and societies where they live; people whose contributions are valuable and needed in the maintenance and creation of eligible communal lives and functioning societies.

While we believe that this is a step in the right direction, the ACRWC understandings about how and for what children should take responsibilities are controversial; Article 31 can arguably be read as justification to nationalist policies and to the use of child labor in familial networks, neither of which we certainly do not wish to endorse. The salient point is that children's agency should not be divorced from their responsibilities. How responsibilities fit into the established framework of children's rights, and how they resonate in different geographical contexts and situations, is hence a challenge for scholars, children's rights advocates, policy makers, and professionals working with children. We see political geographers particularly well equipped to meet these challenges, as the scholarship is well attuned to the contextuality of human rights and to responsibilities as an eminent part of political living, including dimensions of care.

\section{References}

African Charter on the Rights and Welfare of the Child (1990).

http:// pages.au.int/acerwc/documents/african-charter-rights-and-welfare-child-acrwc Accessed 20.01.16.

Baines, E.K. (2015). "Today, I want to speak out the truth": Victim agency, responsibility, and transitional justice. International Political Sociology, 9, 316-332.

Bartos, A. E. (2012). Children caring for their worlds: The politics of care and childhood. Political Geography, 31(3), 157-166. 
This is the authors' copy of the accepted manuscript. For referencing, please use the original: Kallio, K.P. \& Bartos, A.E. (forthcoming) Children's caring agencies. Quest editorial in Political Geography doi:10.1016/j.polgeo.2016.09.009

Bartos, A.E. (2013). Friendship and environmental politics in childhood. Space and Polity 17, 17-32.

Eide, K. \& Hjern, A. (2013). Unaccompanied refugee children-vulnerability and agency. Acta Paediatrica, $102,666-668$.

Ensor, M .O. (2014). Youth culture, refugee (re) integration, and diasporic identities in South Sudan. Postcolonial Text, 8, 3\&4.

Evans, R. (2011). Young caregiving and HIV in the UK: Caring relationships and mobilities in African migrant families. Population, Space and Place, 17, 338-360.

Evans, R. \& Skovdal, M . (2016) Defining children's rights to work and care in Sub-Saharan Africa: Tensions and challenges in policy and practice. In K.P. Kallio \& S. Mills (Eds.), Politics, Citizenship and Rights. Vol. 7 of Skelton, T. (ed.) Geographies of Children and Young People, 89-110. Singapore: Springer.

Habashi, J. (2008). Language of political socialization: language of resistance. Children's Geographies 6 , 269-280.

Habashi, J. (2016). Female political morality in Palestine: Children's perspectives. In K.P. Kallio \& S. Mills (Eds.), Politics, Citizenship and Rights. Vol. 7 of Skelton, T. (ed.) Geographies of Children and Young People, 291-308. Singapore: Springer.

Kallio, K.P. (2008) The body as a battlefield: Approaching children's politics. Geografiska Annaler B: Human Geography 90(3), 285-297.

Kallio, K.P. (2016) Shaping subjects in everyday encounters: Intergenerational recognition in intersubjective socialization. Environment and Planning D: Society and Space. [Published online June 2016].

DOI:10.1177/0263775816654916

Kjørholt, A. T. (2013). Childhood as social investment, rights and the valuing of education. Children \& society, 27(4), 245-257.

Kuusisto-Arponen, A.K. (2011). Transnational sense of place: Cinematic scenes of Finnish war child memories. Journal of Aesthetics \& Culture, 3, DOI:10.3402/jac.v3i0.7178

Lawson, V. (2007) Geographies of care and responsibility. Annals of the Association of American Geographers 97: 1-11.

M arshall, D. (2013). All the beautiful things: trauma, aesthetics and the politics of Palestinian childhood. Space and Polity 17(1), 53-75. 
This is the authors' copy of the accepted manuscript. For referencing, please use the original: Kallio, K.P. \& Bartos, A.E. (forthcoming) Children's caring agencies. Quest editorial in Political Geography doi:10.1016/j.polgeo.2016.09.009

Marshall, D. (2016). Existence as resistance: children and the politics of everyday practice in Palestine. In K.P. Kallio \& S. Mills (Eds.), Politics, Citizenship and Rights. Vol. 7 of Skelton, T. (ed.) Geographies of Children and Young People, 245-262. Singapore: Springer.

NGO Committee on Migration (2015). Three position papers from 2014-2015, written by subcommittees.

http:// www .ohchr.org/Documents/Issues/M igration/StudyM igrants/CivilSociety/ NGOCommitteeM igration. pdf Accessed 18.04.16.

Punch, S. \& Vanderbeck, R.M. (Eds.) (forthcoming). Family, Intergenerationality and Peer-Group Relations.

Volume 5 of Skelton, T. (ed.) Geographies of Children and Young People. Singapore: Springer.

Robson, E. (2004). Hidden child workers: Young carers in Zimbabwe. Antipode, 36, 227-248.

United Nations Committee on the Rights of the Child (CRC). (2009). General Comment No. 12, "The right of the child to be heard". URL: http://www2.ohchr.org/english/bodies/crc/docs/AdvanceVersions/CRC-C-GC12.pdf Accessed 20.01.16.

Ruck, M. D., \& Horn, S. S. (Eds.) (2008). Special Issue on 'Charting the landscape of children's rights'. Journal of Social Issues, 64(4), 685-699.

Tronto, J. C. (1993). Moral boundaries: A political argument for an ethic of care. New York and London: Routledge.

United Nations Convention on the Rights of the Child (UNCRC). (1989).

http://www.ohchr.org/EN/Professionallnterest/Pages/CRC.aspx Accessed 19.01.16.

United Nations High Commission for Refugees (UNHCR). (2015). Global Trends: Forced Displacement in 2014. http://unhcr.org/556725e69.htm|\# ga=1.171505120.159362551.1427455883 Accessed 19.01.16.

Ybarra, M . \& Peña, I. (2016) "We don't need money, we need to be together": Forced transnationality in deportation afterlives. Geopolitics [Published online July 2016]. DOI:10.1080/14650045.2016.1204600

\footnotetext{
i For the current situation, see the UNHCR data: http:// data.unhcr.org/

ii With the exception of the United States that has not ratified the treaty but is a signatory state.
} 